\title{
Implementasi Pembelajaran Berbasis Produk Dalam Rangka Menyiapkan Lulusan Smk Menjadi Wirausahawan Muda
}

\author{
Irma Yulia Basri ${ }^{1 *}$, Delsina Faiza ${ }^{2}$, M. Nasir ${ }^{1}$, Nasrun ${ }^{1}$ \\ ${ }^{1}$ Jurusan Teknik Otomotif, Fakultas Teknik,Universitas Negeri Padang \\ ${ }^{2}$ Jurusan Teknik Elektronika, Fakultas Teknik,Universitas Negeri Padang \\ *Corresponding author, e-mail: irmayuliabasri@yahoo.com
}

\begin{abstract}
Abstrak - Pertumbuhan industri/lapangan kerja tidak sebanding dengan jumlah lulusan SMK menjadikan tingkat persaingan bekerja semakin ketat. Untuk menyiapkan lulusan dan mengurangi angka pengangguran di SMKN 1 Tarusan dan SMKN 2 Painan, maka peneliti mencoba mengimplemtasikan pembelajaran berbasis produk, untuk membuka wawasan siswa tentang wirausaha. Daerah Pesisir Selatan merupakan satu-satunya daerah yang telah mendapatkan predikat Wisata Shar'i, sehingga menjadi peluang bagus bagi alumni SMK untuk berkreasi menciptakan produk inovatif yang bernilai jual sebagai cendramata wisata daerah Pesisir Selatan. Metode pmebelajaran berbasis produk ini menerapkan rancangan penelitian $R \& D$. Produk yang dihasilkan sampel penelitian adalah Lampu Hias dari Stick es Krim. Implementasi pembelajaran berbasis produk telah mampu meningkatkan minat peserta didik untuk berwirausaha sebesar $44 \%$.
\end{abstract}

Kata Kunci : Siswa SMK, Pembelajaran Berbasis Produk, Lampu Hias Stick Es Krim, Minat Berwirausaha

\begin{abstract}
Industrial growth is not comparable to the number of SMK graduates making the level of competition work increasingly tight. To prepare graduates and reduce unemployment rates at SMKN 1 Tarusan and SMKN 2 Painan, the researchers tried to implement product-based learning to open up students' knowledge about entrepreneurship. The South Coast region is the only area that has received the Shar'i Tourism predicate, making it a good opportunity for SMK alumni to be creative in creating innovative products that are worth selling as tourism objects in the South Coast region. This product-based learning method applies $R \& D$ research design. The product produced by the research sample was the Decorative Lamp from the Ice Cream Stick. The implementation of productbased learning has been able to increase student interest in entrepreneurship by $44 \%$.
\end{abstract}

Keywords : Vocational Students, Product-Based Learning, Ice Cream Stick Lights, Entrepreneurial Interest

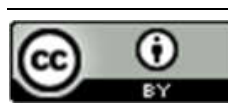

This is an open access article distributed under the Creative Commons 4.0 Attribution License

\section{Pendahuluan}

Pesisir Selatan salah satu daerah tujuan wisata yang lagi giat dikembangkan oleh pemerintah Sumatera Barat. Anugerah pertama sebagai The Most Popular Hiden Paradise, harusnya menjadikan peluang usaha yang sangat bagus untuk meningkatkan taraf ekonomi masyarakat Pesisir Selatan. Kesempatan peluang usaha ini harusnya dimanfaatkan oleh sekolah-sekolah kejuruan di daerah Pesisir Selatan untuk menyiapkan alumninya dalam membuka peluang kerja sendiri. Hal ini dikarenakan tingkat keterserapan lulusan SMK untuk bekerja sesuai bidang keahliannya yang ada di daerah Pesisir Selatan masih kurang dari $50 \%$ dari jumlah total lulusan yang ada. Hal ini disebabkan oleh keterbatasan fasilitas pratikum, ilmu yang diberikan kurang bisa mengikuti teknologi yang ada, serta jumlah guru produktif yang masih kurang di beberapa program keahlian. Pembelajaran kewirausahaan masih bersifat teoritis, belum menyentuh ide-ide kreatif peserta didik untuk bisa menghasilkan produk-produk yang layak jual sesuai dengan ilmu yang mereka pelajari di program keahliannya. Pertumbuhan 
industri/lapangan kerja tidak sebanding dengan jumlah lulusan SMK menjadikan tingkat persaingan bekerja semakin ketat.

Menteri Pendidikan dan Kebudayaan di Kabinet Kerja menilai evaluasi tentang perencanaan kebutuhan tenaga kerja belum sesuai dengan permintaan stakeholder, sehingga tenaga kerja yang disiapkan banyak menjadi pengangguaran, karena keterampilan yang diebrikan semenjak mereka mengikuti pendidikan formal tidak relevan dengan kebutuhan industri. Mendikbud berharap perencanaan kebutuhan tenaga kerja sebaiknya memperhatikan kebutuhan di wilayah regional, sehingga kurikulum yang diberikan kepada siswa relevan dengan kebutuhan stakeholder di wilayah mereka tinggal, dan saat mereka tamat dari pendidikan formal dapat bekerja langsung [4].

Masalah lain yang dihadapi SMK adalah jumlah guru produktif tidak sebanding dengan jumlah siswa SMK [6]. Pengangkatan guru produktif melalui jalur PNS sangat sulit dilakukan, dikarenakan terbatasnya anggaran dan masih banyaknya guru adaptif dan normatif yang kekurangan jam mengajar. Pemerintah saat ini untuk mengatasi masalah diatas dengan melakukan Program Keahlian Ganda. Akan tetapi keahlian ganda yang diberikan kepada guru adaptif dan normatif dalam beberapa bulan, belum menjadi solusi yang tepat dalam peningkatan kualitas tamatan SMK. Hal ini terlihat dari sebagian besar guru-guru keahlian ganda tidak menguasai materi produktif yang akan di ajarkan di SMK. Kualitas guru produktif yang kurang akan menjadikan kemampuan dan keahlian yang dimilik tamatan SMK juga berkurang.

Prosentase lulusan SMK yang bisa langsung bekerja di perusahaan sangat sedikit. Sebagian besar lulusan SMk jika tidak melanjutkan studinya di perguruan tinggi, mereka umumnya menjadi pengangguran [4]. Kemampuan dan keterampilan yang terbatas yang dimilki oleh lulusan SMK, membuat perusahaan sebagai penyedia lowongan kerja, enggan untuk merekrut mereka bergabung di perusahaan tersebut, dan ini menjadi tantangan bagi SMK, bagaimana menekan angka pengangguran lulusan SMK seminim mungkin.

Program pengembangan kewirausahaan dikalangan SMK terus dikembangkan oleh Direktorat Pembinaan Sekolah Menengah Kejuruan (SMK) Kementerian Pendidikan dan Kebudayaan (Kemendikbud). Kepala sekola di SMK dituntut lebih banyak mengasilkan wirausahawan muda. Program yang dikembangkan oleh Kemendikbud dengan mengkombinasikan pendidikan kewirausahaan di SMK dengan program BMW. BMW merupakan singkatan dari "Belajar, Melanjutkan Studi dan Wirausaha". Pembelajaran kewirausahaan yang terintegrasi dengan program BMW memfokuskan pembelajaran berbasis produksi dan bisnis. Mata pelajaran Kewirausahaan saat ini tidak hanya membahas tentang aspek teoritis, akan tetapi peserta didik SMK dituntut untuk menghasilkan produk inovatif sesuai dengan bidang keahliannya, sehinga mata pelajaran Kewirausahaan, diganti dengan nama Produk Kreatif dan Kewirausahaan. Direktorat pembinaan SMK pada tahun 2018 menerapkan program SPW (SMK Pencetak Wirausaha). Jumlah sekolah yang ikut dalam kegiatan SPW angkatan pertama adalah 114 sekolah. Model pembelajaran yang diterapkan dalam mengaplikasikan program SPW adalah dengan membina peserta didik untuk memiliki keterampilan melalui praktik usaha berbasis online. Praktik ini dinilai lebih praktis dan tidak membutuhkan modal yang besar dibandingkan dengan sistem pemasaran konvensional. Target dari program SPW adalah 5\% dari lulusan dapat menciptakan lapangan pekerjaan sendiri [7].

Meski tugas pemerintah berfokus kepada lulusan SMK siap bekerja di perusahaan, akan tetapi karena pertumbuhan perusahaan nasional dengan pertumbuhan lulusan SMK tidak sebanding, sehingga kebutuhan tenaga kerja untuk di industri tidak sebanyak lulusan SMK tahun ke tahun. Untuk mengirimkan lulusan SMK bekerja ke luar negeri, mereka harus mempunyai keterampilan tambahan, terutama kemampuan berbahasa asing baik secara pasif maupun aktif. Hal yang terjadi sampai saat ini, peserta didik selama menempuh pendidikan di SMK, belum dipersiapkan sepenuhnya untuk harus menguasai kemampuan berbahasa asing. Hal ini menjadi dilema, jika hanya mengandalkan bekerja di industi nasional persaingan cukup ketat karena kebutuhan tenaga kerja tidak sebanding dengan jumlah lulusan SMK dari tahun ketahun, dan jika akan bekerja ke luar negeri, peserta didik SMK belum menguasai kemampuan berbahasa asing baik aktif dan pasif, selain penguasaan keterampilan vokasi yang juga masih terbatas. Oleh sebab itu untuk mengurangi angka penganguran di Indonesia, lulusan SMK selain dipersiapkan meningkatkan keterampilan vokasi dan kemampuan berbahasa asing, mereka juga harus dibekali dengan menumbuhkan minat berwirausaha untuk bisa membuka lapangan kerja sendiri dengan modal yang seminim-minimnya.

Tantangan yang dihadapi bagi pengajar kewirausahaan adalah menggali potensi peserta didik dan lingkungan sekitar untuk bisa membuka 
cakrawala dan keterampilan peserta didik dalam menghasilkan produk yang bernilai jual selama mereka menempuh pendidikan di SMK. Guru pengajar kewirausahaan harus berkolaborasi dan bersinergi dengan guru-guru produktif untuk merumuskan produk apa yang bisa dihasilkan oleh peserta didik tiap semester selama belajar kewirausahaan. Peluang untuk menghasilkan produk yang bernilai jual di SMK sangat besar, seperti Program Studi Teknik Bangunan, bisa menghasilkan mini furniture sebagai pajangan dinding. Jurusan Teknik Mesin, dengan teknologi las, peserta didik akan mampu menghasilkan terali besi yang dibutuhkan oleh masyarakat sekitar sekolah. Jurusan Teknik Elektronika akan mampu menghasilkan produk berupa Lampu Teras Otomatis, Bel Pintu, Lampu Hias dan lain-lain.

Berdasarkan wawancara yang dilakukan peneliti terhadap SMKN 1 Tarusan dan SMKN 2 Painan, kendala utama sekolah untuk membuat Teaching Factory adalah sarana dan prasarana yang kurang memadai. Tetapi peneliti disini melihat, untuk memulai menghasilkan produk sederhana yag bernilai jual tidak selalu membutuhkan modal besar, memanfaat bahan yang murah dan mudah ditemukan dilingkungan sekitar juga bisa dilakukan. Pembelajaran yang outcomenya mampu menghasilkan benda nyata akan menambah keaktifan dari peserta didik selama proses belajar berlangsung. [2] mengemukakan bahwa pendidikan berbasis produk yang diterapkan pada Sampel peserta didik SMKN 1 Tarusan dan SMKN 2 Painan, mampu menciptakan pembelajaran yang kreatif, antusias serta mampu meningkatkan minat peserta didik untuk berwirausaha.

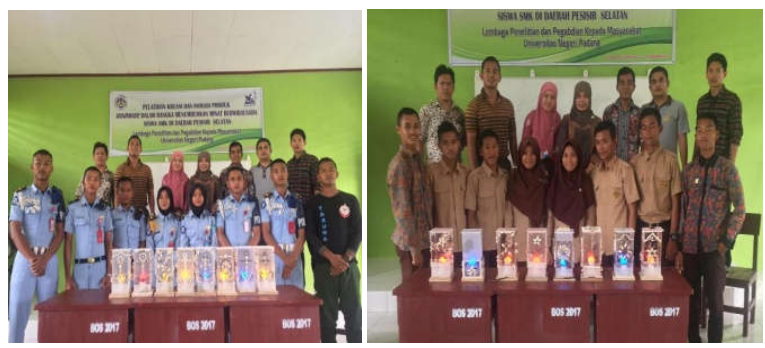

Gambar 1. Produk Handmade yang dihasilkan Siswa [2]

\section{Studi Pustaka}

\section{A. Pembelajaran Berbasis Produk}

Pembelajaran berbasis produk (Product Based Learning) merupakan salah satu model pembelajaran yang direkomendasikan UndangUndang Pendidikan untuk diterapkan di SMK.
Pembelajaran ini mensinkronkan antara pengetahuan pembelajaran teori dengan keterampilan yang didapatkan siswa SMK saat kegiatan pratikum berlangsung. Kombinasi antara pengetahuan dan keterampilan, diharapkan siswa SMK dapat mengasilkan produk yang bernilai jual yang sesuai dengan bidang keahliannya. Sebetulnya, siswa SMK dari dulunya terutama di program studi Elektronika Teknik AudioVideo, sudah menghasilkan produk berupa Tape dan Amplifier yang sudah layak jual, sebagai tugas akhir dari siswa tersebut, hanya saja produk yang dihasilkan hanya digunakan untuk keperluan mereka sendiri. Padahal ini merupakan keterampilan yang bisa mereka jadikan sebagai modal usaha dalam membuka lapangan pekerjaan sendiri. Apalagi dari kelas XI mereka sudah dilatih dalam mengasilkan rangkaian elektronika yang bisa digunakan dalam kehidupan sehari-hari, seperti alarm rumah untuk menghindari pencurian, lampu teras otomotis, bell pintu dan rangkaian power supply. Akan tetapi karena penekanan dampak dari keterampilan yang mereka miliki tersebut tidak dijelaskan secara spesifik, sehingga pengetahuan dan keterampilan mereka tersebut tidak mendorong mereka untuk membuka peluang usaha sendiri.

Tantangan pendidikan SMK yang dihadapi saat ini adalah bagaimana pemerintah mampu menambah jumlah guru-guru vokasional yang berkualitas. Penyebaran guru-guru vokasional yang berkualitas dan latar belakang keilmuannya yang sesuai dengan kebutuhan SMK, untuk daerahdaerah tertentu masih belum terpenuhi. Seperti daerah Jambi, Palembang dan Bengkulu. SMK dengan program studi Teknik Otomotif, guru vokasional yang berlatar belakang pendidikan S1 Pendidikan Teknik Otomotif hanya 2-4 orang, sementara jumlah siswa dari Kelas XI sampai Kelas XII lebih dari 200 orang. Kekurangan guru produktif di bidang Teknik Otomotif, diantisipasi dengan memberdayakan guru dari latar belakang pendidikan mesin dan guru-guru non teknik yang sudah mengikuti dan mendapatkan sertifikat Keahlian Ganda. Kualitas guru yang relevan dengan program keahlian akan sangat berpegaruh terhadap kualitas lulusan SMK yang dihasilkan. Target dari pemerintah, tentang $70 \%$ lulusan SMK pada tahun yang sama harus bisa bekerja akan sangat sulit tercapai, jika SDM yang di berdayakan untuk kemajuan SMK tidak relevan latar belakang pendidikannya.

Pendidikan di SMK yang berkualitas juga tidak terlepas dari kurikulum yang diterapkan di SMK. Kurikulum harus relevan dengan kebutuhan 
perusahaan yang menerima jasa tenaga kerja SMK. Penyesuaian kurikulum SMK dengan kebutuhan industry dapat dilakukan dengan penjajakan ke dunia industri. Kompetensi apa yang lagi dibutuhkan oleh dunia kerja untuk jangka pendek dan jangka panjang. Berdasarkan hasil penjajakan tersebut maka mata pelajaran akan disesuaikan dengan kebutuhan kompetensi yang dibutuhkan. Masalah lain yang dihadapi oleh lulusan SMK adalah kurangnya industri di daerah-daerah yang cukup banyak mengasilkan lulusan SMK, seperti di daerah Sumatera Barat. Lulusan SMK dari daerah ini akan exodus ke Kota Batam untuk mencari kesempatan kerja. Tidak semua lulusan SMK yang dapat melakukan hal tersebut terutama untuk lulusan SMK yang secara ekonomi kurang dan keluarga tidak ada di Batam, sehingga beberapa dari lulusan SMK menjadi pengangguran di kampung halamannya. Untuk mengatasi hal tersebut maka pembelajaran kewirausahaan harus lebih ditingkatkan perannya untuk mengatasi angka pengangguran di SMK.

Kewirausahaan yang selama ini hanya mengajarkan aspek teorits, saat ini guru-guru pembina mata pelajaran kewirausahaan harus berkolaborasi dengan guru produktif untuk memberdayakan siswa dalam mengasilkan produk kreatif yang bernilai jual sesuai dengan bidang kompetensi siswa. Contoh jurusan mesin dengan keahlian bisa melakukan las besi dan baja, produk yang dihasilkan selama siswa tersebut belajar kewirausahaan adalah mengasilkan terali besi yang bisa dimanfaakan oleh sekolah maupun bisa dijual ke masyarakat sekitar. Program Kahlian Teknik Banggunan bisa mengasilkan kotak pensil dari kayu dengan memanfaatkan kayu-kayu bekas. Pembelajaran kewirausahaan yang produktif diharapkan mampu menyiapkan siswa menjadi wirausaha muda sehingga saat mereka tamat SMK tidak hanya mengandalkan kesempatan kerja di perusahaan orang lain, akan tetapi mereka siap untuk membuka peluang usaha sendiri.

Untuk menjadi seorang wirausahawan, perlu di pelajari aspek-aspek yang menjadi kendala dalam membuka wirausaha. Mempelajari proses menjadi wirausahaan dari wirausahaawan sukses akan menjadi pengaruh dalam memutuskan untuk berwirausaha [15]. Hal yang perlu diperhatikan dalam memutuskan untuk berwirasusaha adalah bagaiman mengindentifikasi peluang pasar dari jasa/produk yang akan dihasilkan, dan perhitungkan kemungkinan keuntungan yang akan di dapat dari peluang usaha tersebut. seorang wirausahawan harus mampu melakukan inovasi dan kreasi dari produk atau jasa yang ditawarkan.
Misalkan, kotak pensil yang dihasilkan dari kayu bekas dikolabaroasikan dengan lampu belajar yang dudukannya dterbuat ari tempurung kelapa. Calon wirausahawan sukses juga mampu memprediksi peluang dan kemungkinan keuntungan dari usaha yang akan dia geluti. Seorang wirausahawan juga harus mampu membaca cash flow dan meningkatkan cash flow yang positif dari peluang usaha yang ditekuni. Wirausahawa haus jeli membaca peluang dan mamp bersaing dengan usaha/jasa yang sejenis. Peluang usaha yang berkualitas dan mempunyai karakteristik tertentu yang akan mampu bertahan dalam persaingan dunia usaha.

Menurut [1] dalam Hari membudayakan kewirausahaan dikalangan peserta didik dikemas melalui sebuah proses pembelajaran kewirausahaan melalui lima kegiatan:

1. Peserta didik diwajibkan mengikuti kegiatan "pembakaran" motivasi khususnya membangun kekuatan karakter menjadi wirausaha,

2. Peserta didik diwajibkan mengikuti konseptualisasi dan integrase pengetahuan manajemen bisnis

3. Peserta didik diwajibkan mengikuti kegiatan pemagangan, kunjungan, dan konsultasi kewirausahaan dengan mitra industri

4. Peserta didik diwajibkan untuk merefleksikan pengalaman belajar kewirausahaan di lapangan

5. Peserta didik diwajibkan untuk mempersiapkan start up bisnis dan mengikuti layanan pembimbingan.

Siklus pembelajaran pengalaman tindakan berlangsung dimana peserta didik secara individual berinteraksi dengan orang-orang dan lingkungan usaha. Pembelajaran kewirausahaan berbasis kompetensi dan pengalaman akan cenderung bersifat dinamis, kontekstual, dan intuitif dalam melibatkan peserta didik belajar berinteraksi dengan lingkungan bisnis, jaringan sosial, dan pekerjaan sendiri.

Pembelajaran berbasis produk merupakan proses model pembelajaran yang berfokus kepada outcome peserta didik mampu mengasilkan produk ataun jasa di akhir pembelajaran [5]. Produk atau jasa yang dihasilkan layak dipasarkan dan dapat diterima oleh masyarakat. Tentunya model pembelajaran berbasis produk sejalan dengan konsep pendidikan kejuruan. Model pembelajaran berbasis produk didefinisikan sebagai prosedur yang harus diikuti siswa saat pembelajaran agar aktif, kreatif, inovatif dan mampu berkomunikasi dan berintekasi sosial dengan bagus, diakhir 
pembelajaran, peserta didik dituntut mengasilkan produk ataupun jasa yang bernilai jual. Sedangkan menurut [11] pembelajaran berbasis produk menggunakan proses produksi sebagai media pembelajarannya.

Peserta didik memiliki bekal yang sesuai dengan tuntutan masa depan berupa kemampuan menghasilkan produk atau jasa, dan juga mempunyai sikap wirausaha yang didapatkan berdasarkan pengalaman melakukan produksi barang atau jasa merupakan tujuan dari pembelajaran berbasis produk. Faktor pendukung keberhasilan pembelajaran berbasis produk adalah: a) Fasilitas yang terstandarisasi, b) Pendidik atau instruktur yang bersertifikat, c) Pengalaman tambahan untuk menjamin kesiapan kerja, d) Penghargaan terhadap kepuasan konsumen, e) Komitmen untuk menjaga kualitas [3].

Faktor lainnya yang membantu keberhasilan pengaplikasian model pembelajaran berbasis produk: kompetensi dosen/instruktur, kesiapan mahasiswa/peserta didik, tersedianya peralatan dan bahan sesuai dengan kebutuhan, dan modal yang cukup besar [14]. Pembelajaran Berbasis Produk, dengan menggabungkan dengan Virtual Library mampu membuat pembelajaran lebih berorientasi kepada siswa, siswa lebih cendrung aktif dan pembelajaran lebih interaktif [16].

Kemampuan peserta didik tidak hanya ditinjau dari kompeten atau tidak, penilaian pada pembelajaran berbasis produk lebih menekankan pada hasil yang secara fungsi berhubungan dengan performa kerja produk yang dihasilkan. Dan faktor yang paling penting pada penilaian kemampuan peserta didik untuk menyelesaikan produk sesuai dengan waktu yang diberikan. Maka kemampuan membuat produk untuk dalam waktu yang cepat adalah hal yang utama.

Kemudahan peserta didik untuk memahami dan menyerap materi pelajaran merupakan hal yang ditekankan pada model pembelajaran berbasis produk. Peserta didik mampu belajar secara efektif karena konsep pembelajaran ini tidak hanya meninjau pencapaian hanya pada standar kompetensi, juga waktu yang dibutuhkan peserta didik untuk mencapai standar tersebut secepatnya. Dengan demikian peserta didik akan terbiasa membuat produk secara efisien, dan lebih produktif [13].

Metode pembelajaran berbasis produk diimplementasikan pada beberapa perguruan tinggi atau sekolah tinggi di Indonesia dengan kerja sama dunia usaha dan industri. Metode ini juga membuat lulusan dari perguruan tinggi maupun sekolah mempunyai kemampuan menghasilkan barang atau jasa, sehingga nantinya lulusan tidak hanya menjadi pekerja, tetapi mampu menjadi pelaku usaha.

Lulusan SMK belum sesuai dengan keinginan dunia kerja karena kemampuannya masih setengah terampil dan masih lemahnya watak kepribadian dalam menghadapi tantangan. Oleh karena itu, perlu diterapkan di SMK teknologi pengembangan pembelajaran berbasis produk [8]. Lulusan yang memenuhi standar nasional dan internasional merupakan karakteristik dari metode pembelajaran berbasis produk. Aspekaspek yang diutamakan pada pembelajaran ini adalah:

1. Desain

Desain prosedur yang terorganisir harus dimiliki dalam sistem pembelajaran seperti langkah-langkah analisa, rancangan, pengembangan, aplikasi, dan penilaian pembelajaran.

2. Pengembangan

Proses pengembangan termasuk pada sumber belajar cetak, teknologi audio visual, dan teknologi berbasis komputer.

3. Pemanfaatan

Menggunakan semua sumber dalam aktifitas belajar.

4. Pengelolaan

Pegawasan berdasarkan perencanaan, pengorganisasian, dan pengkoordinasian.

5. Evaluasi

Pengujian keberhasilan metode pembelajaran.

Agar peserta didik mampu menjadi lulusan yang sesuai dengan keluaran dari model pembelajaran berbasis produk, beberapa hal yang perlu ditekankan adalah [10]:

1. Peserta didik dalam pembelajaran harus terlibat secara intelektual dan emosional.

2. Setiap peserta didik dapat menemukan dan membangun konsep yang sedang dikaji melalui cara-cara seperti observasi, diskusi, percobaan, dan pemahaman.

3. Peserta didik bertanggung jawab dalam menyelesaikan tugas.

4. Peserta didik memiliki sikap kerja keras, dedikasi tinggi, dan antusias.

\section{B. Wirausaha}

Wirausaha merupakan sebuah upaya untuk masuk ke dalam sistem ekonomi dengan memperkenalkan barang atau jasa tertentu, menciptakan organisasi, atau mengolah sebuah produk. Inti dari wirausaha (1) kemampuan melakukan sebuah kegiatan usaha; (2) Tiada henti 
untuk berkreativitas dan inovasi dalam menemukan sesuatu hal baru dari yang sudah ada, dan (3) kontribusi dari hasil kreativitas dan inovasi kepada masyarakat.

Wirausaha memiliki beberapa manfaat seperti (1) menambah lapangan kerja baru, sehingga pengangguran berkurang; (2) menggerakkan pembangunan pada lingkungan sekitar; (3) memberikan bantuan pembangunan sosial terhadap masyarakat sekitar; (4) pendidikan kepada karyawan agar menjadi mandiri, disiplin, jujur, tekun dalam melakukan pekerjaan; (5) menjadi contoh dalam bekerja keras; (6) efisiensi terhadap hasil kerja.

Minat wirausaha merupakan keinginan seseorang untuk bekerja keras dan berusaha menjalankan kreatifitas dan ide-ide yang telah dipikirkan. Keinginan ini didorong oleh kebutuhan hidup yang harus dipenuhi dan menerima tantangan secara percaya diri, kreatif, dan inovatif. Pelaku wirausaha tidak merasa takut dengan resiko yang akan terjadi karena mempunyai kemampuan dan keterampilan dalam mengatasi resiko tersebut.

\section{METODE}

Jenis penelitian yang digunakan adalah Research and Development (Penelitian dan Pengembangan). Metode R\&D merupakan penelitian yang digunakan untuk menghasilkan produk tertentu dan menguji keefektifan produk tersebut [12]. Tahapan penelitian pengembangan pada penelitian ini adalah analisis kebutuhan, desain produk, revisi desain, pembuatan produk, ujicoba pemakaian, evaluasi dan revisi produk, dan produksi massal.

1. Analisis kebutuhan

Analisis kebutuhan berkaitan dengan pesisir selatan sedang digalakkan pemerintah Sumatera Barat sebagai kota wisata dan telah mendapatkan penghargaan sebagai wisatawan syar'i. Peluang usaha bagi tamatan SMK di Pesisir Selatan untuk menghasilkan produk yang bisa dijadikan sebagai cendramata wisata sangat terbuka luas, sehigga tingkat pengangguran lulusan SMK di daerah tersebut bisa di kurangi. Produk yang akan dihasilkan dalam pembelajaran ini adalah Lampu Hias dari Stick Es krim

2. Desain Produk

Desain produk lampu hias dari stick es krim di adopsi dari video yang beredar di youtube tentang kreasi stick es krim dalam menciptakan produk lampu hias. Desain yang ditawaran kepada siswa ada 2 jenis desain tetapi siswa tidak diharuskan membuat persis seperti contoh desain yag diberikan, peserta didik bisa berkreasi sendiri.

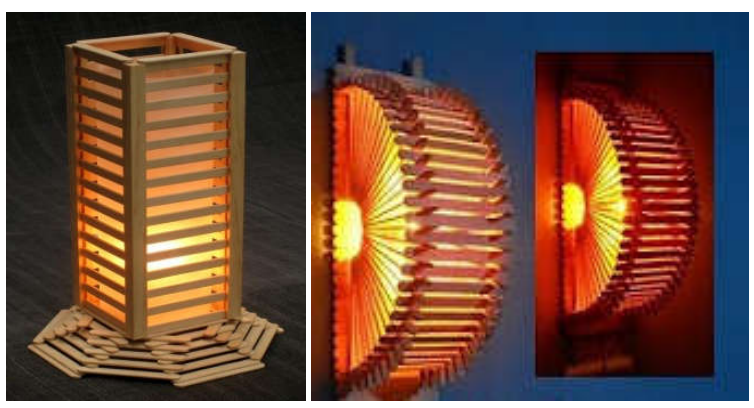

Gambar 2. Contoh Design Produk

3. Validasi Desain

Validasi desain rancangan lampu hias yang dibuat peserta didik dilakukan oleh instruktur. Validasi desain terdiri dari bentuk rancangan, ukuran rancangan, tata letak petting lampu dan kekuatan rancangan.

\section{Revisi Desain}

Revisi desain yang dilakukan peserta didik umumnya terdiri dari ukuran rancangan yang tidak memungkikan petting lampu dan lampu berada di dalam produk yan dihasilkan, sehingga dilakukan perbaikan rancangan.

\section{Pembuatan Produk}

Desain produk yang sudah direvisi kemudian dilakukukan perakitan produk dengan tahapan sebagai berikut: instalasi stick es krim dengan menggunakan lem lilin sesuai dengan rancangan yang telah dibuat

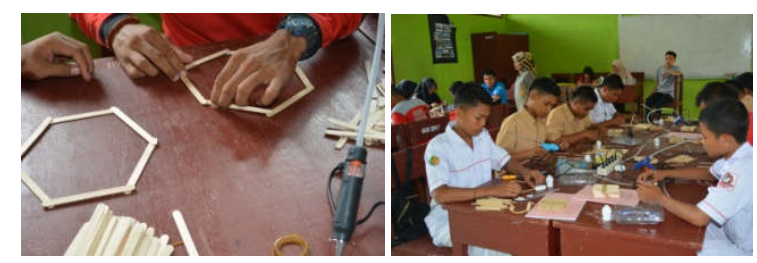

Gambar 3. Proses Pembuatan Produk

\section{Ujicoba Produk}

Produk yang sudah selesai di ujicoba baik untuk menentukan simetris posisi dan instalasi kabel.

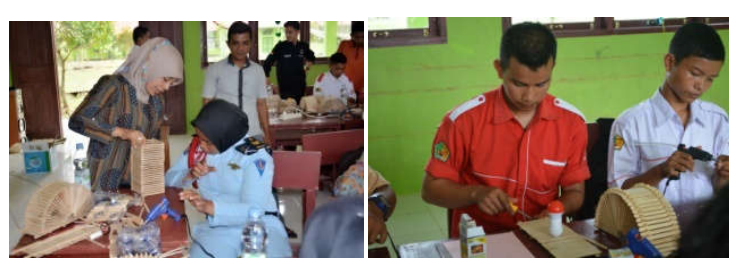

Gambar 4. Validasi Produk 


\section{Evaluasi dan Revisi}

Dari 32 produk yang dihasilkan oleh peserta didik, 2 diantara belum berhasil dikarenakan salah pemasangan saklar dan kesalahan dan pengkabelan, 4 produk yang dihasilkan peserta didik tidak simetris sehingga meski dilakukan revisi dengan cara pembongkaran kembali stick es krim dan menyusun kembali seperti rancangan. Produk yang tidak simetris menjadikan bagian alas lampu hias tidak bertemu dengan bagian utamanya.

\section{Produk Akhir}

Produk yang sudah di revisi dan telah sesuai dengan hasil evaluasi validator, dilakukan proses tahap akhir yaitu pengecatan untuk meberikan kesan berkilau dari lampu hias stick es krim.

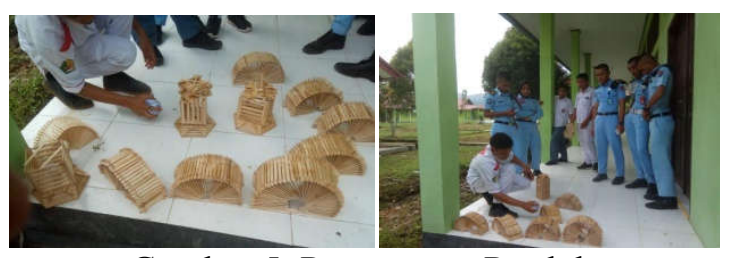

Gambar 5. Pengecatan Produk

Produk akhir yang dihasilkan adalah sebagai berikut:
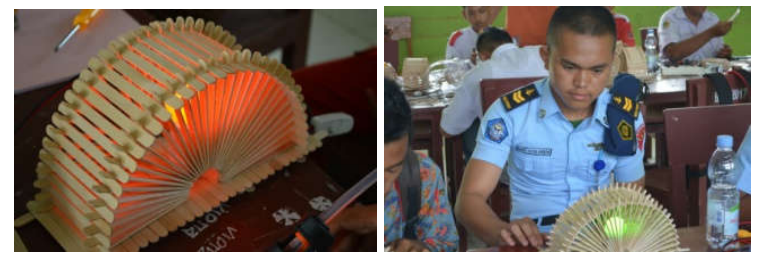

Gambar 6. Produk yang di Hasilkan

\section{HASIL DAN PEMBAHASAN}

Implementasi pembelajaran berbasis produk dapat meningkatkan pengetahuan, keterampilan dan wawasan peserta didik tentang berwirausaha. Sebelum pembelajaran berbasis produk diterapkan, instrument yang disebarkan kepada sampel menghasilkan data seperti pada Tabel 1.

Pembelajaran berbasis produk untuk menyiapkan peserta didik SMKN 1 Tarusan dan SMKN 2 Painan menjadi wirausahawan muda dimulai dengan pemberian materi tentang wirausaha. Materi ini membahas tentang pengertian wirausaha, kiat-kiat menjadi wira usaha, produk dilingkungan sekitar yang berpeluang dikembangkan dan pemberian motivasi tentang paparan profil wirausahawan muda Indonesia yang telah sukses, dengan modal awal membangun usaha yang kecil. Pemberian materi ini bertujuan supaya peserta didik mengubah mindset-nya jika untuk menjadi wirausaha bukan modal besar yang utama diperlukan, akan tetapi adalah produk dan peluang pasar yang bisa dikuasai. Materi yang disajikan juga membahas tentang produk-produk kreatif yang bernilai jual akan tetapi hanya dengan modal usaha yang kecil.

Tabel 1. Data Sebelum Pembelajaran Berbasis Produk

\begin{tabular}{|l|l|l|}
\hline No & Pernyataan & $\%$ \\
\hline 1 & $\begin{array}{l}\text { Kemampuan saya memadai untuk } \\
\text { bersaing mendapatkan pekerjaan } \\
\text { di industri }\end{array}$ & $\begin{array}{l}30 \\
\text { menjawab } \\
\text { memadai }\end{array}$ \\
\hline 2 & $\begin{array}{l}\text { Saya sangat berminat untuk } \\
\text { menjadi wirasusaha }\end{array}$ & $\begin{array}{l}32 \\
\text { menjawab } \\
\text { memadai }\end{array}$ \\
\hline 3 & $\begin{array}{l}\text { Saat tamat SMK nanti saya akan } \\
\text { berwirausaha (menciptakan } \\
\text { lapangan kerja sendiri) }\end{array}$ & $\begin{array}{l}26 \% \\
\text { Menjawab } \\
\text { Ya }\end{array}$ \\
\hline 4 & $\begin{array}{l}\text { Saya sudah punya rencana usaha } \\
\text { yang akan saya rintis dan bangun } \\
\text { saat tamat SMK nanti }\end{array}$ & $\begin{array}{l}\text { Menjawab } \\
\text { Ya }\end{array}$ \\
\hline 5 & $\begin{array}{l}\text { Saya sangat berminat membaca } \\
\text { kisah orang-orang yang berhasil } \\
\text { menjadi wirausahawan sukses di } \\
\text { usia muda }\end{array}$ & $\begin{array}{l}\text { Menjawab } \\
\text { Ya }\end{array}$ \\
\hline 6 & $\begin{array}{l}\text { Untuk menjadi wirausahawan } \\
\text { saya percaya akan membutuhkan } \\
\text { modal awal yang besar }\end{array}$ & $\begin{array}{l}83 \% \\
\text { Menjawab } \\
\text { Ya }\end{array}$ \\
\hline
\end{tabular}

Pemberian wawasan tersebut membuat sampel penelitian menjadi antusias untuk bertanya dan menunjukkan ketertarikan mereka terhadap dunia usaha. Setelah paparan tetang wirausaha dan produk-produk kreatif dipaparkan, materi pelajaran kemudian membahas tentang proses pembuatan lampu hias dengan memanfaatkan stick es krim. Materi disajikan lengkap dengan video sehingga memudahkan penyerapan materi bagi peserta didik. Peserta didik kemudian melanjutkan merancang, merakit dan instlasi lampu hias dari stick es krim. Pengalaman menciptakan produk sendiri bagi peserta didik akan menjadi modal dasar untuk mereka kembangkan menghasilkan produk kreatif lainnya yang bernilai jual.

Setelah pembelajaran berbasis produk diperoleh respon dari siswa seperti yang ada pada tabel 2 . Dari perbandingan tabel 1 dengan tabel 2 tersebut, dapat dilihat terjadi peningkatan minat peserta didik untuk berwirausaha. 
Tabel 2. Data Setelah Pembelajaran Berbasis Produk

\begin{tabular}{|l|l|l|}
\hline No & Pernyataan & $\%$ \\
\hline 1 & $\begin{array}{l}\text { Kemampuan saya memadai untuk } \\
\text { bersaing mendapatkan pekerjaan } \\
\text { di industi }\end{array}$ & $\begin{array}{l}30 \\
\text { menjawab } \\
\text { memadai }\end{array}$ \\
\hline 2 & $\begin{array}{l}\text { Saya sangat berminat untuk } \\
\text { menjadi wirasusaha }\end{array}$ & $\begin{array}{l}67 \\
\text { menjawab } \\
\text { memadai }\end{array}$ \\
\hline 3 & $\begin{array}{l}\text { Saat tamat SMK nanti saya akan } \\
\text { berwirausaha (menciptakan } \\
\text { lapangan kerja sendiri) }\end{array}$ & $\begin{array}{l}70 \% \\
\text { Menjawab } \\
\text { Ya }\end{array}$ \\
\hline 4 & $\begin{array}{l}\text { Saya sudah punya rencana usaha } \\
\text { yang akan saya rintis dan bangun } \\
\text { saat tamat SMK nanti }\end{array}$ & $\begin{array}{l}68 \% \\
\text { Menjawab } \\
\text { Ya }\end{array}$ \\
\hline 5 & $\begin{array}{l}\text { Saya sangat berminat membaca } \\
\text { kisah orang-orang yang berhasil } \\
\text { menjadi wirausahawan sukses di } \\
\text { usia muda }\end{array}$ & $\begin{array}{l}74 \% \\
\text { Menjawab } \\
\text { Ya }\end{array}$ \\
\hline 6 & $\begin{array}{l}\text { Untuk menjadi wirausahawan } \\
\text { saya percaya akan membutuhkan } \\
\text { modal awal yang besar }\end{array}$ & $\begin{array}{l}\text { Menjawab } \\
\text { Ya }\end{array}$ \\
\hline
\end{tabular}

\section{KESIMPULAN}

Implementasi pembelajaran berbasis produk telah mampu meningkatkan minat peserta didik untuk berwirausaha sebesar $44 \%$. Antusias siswa dalam mengikuti pembelajaran tinggi, sehingga produk yang dihasilkan selama pembelajaran berkualitas dan bernilai jual di pasaran.

\section{DAftar Pustaka}

[1] Badraningsih Lastariwati. 2012. Pentingnya Kelas Kewirausahaan Pada SMK Pariwisata. Jurnal Pendidikan Vokasi, Februari 2012, Vol 2, Nomor 1 hal $71-80$.

[2] Basri, dkk. 2017. Application Of Learning Based Products In Order To Grow Interest In Entrepreneurship Of Vocational Students. Proceedings ICTVET page 365-369. ISBN 978-602-1178-1-9

[3] Kemendikbud. 1999. Kurikulum Sekolah Menengah Kejuruan. Jakarta : Pendidikan Menegah dan Kejuruan.

[4] Effendy, Muhadjir. 2016. Ini Penyebab Lulusan Sekolah Vokasi Banyak Yang Menganggur. Republika, 25 Oktober 2016

[5] Ganefri, G. 2013. The Development of Production-Based Learning Approach to Entrepreneurial Spirit for Engineering Students. Asian Social Science, 9(12) hal 162167.

[6] Kemendukbud. 2015. Rencana Strategis Kementrian Pendidikan dan Kebudayaan
2015-2019. Jakarta: Kemendikbud. www.planipolis.iiep.unesco.og

[7] Kemendikbud. 2018. Kemendikbud Dorong SMK Ciptakan Wirausaha Muda. https://www.kemdikbud.go.id/main/blog/2018 /06/kemendikbud-dorong-smk-ciptakanwirausaha-muda

[8] Marlina. 2017. Pengembangan Model Pelatihan Berbasis Produksi Pada Pendidikan Vokasional. Prosiding Seminar APTEKINDO, Hal $481-488$.

[9] Miory, Dwiprima Elvanny dkk. 2017. Korelasi minat berwirausaha dengan kinerja praktik kerja industri siswa SMK. Jurnal Invotek, April 2017, Volume 17 No 1.

[10]Mursid, R. 2013. Pengembangan Model Pembelajaran Praktik Berbasis Kompetensi Berorientasi Produksi. Jurnal Cakrawala Pendidikan, Februari 2013, Th. XXXII, No. 1. Nani Rohaeni. 2007. Penerapan Pendekatan Production Based Training pada Mata Diklat Pengolahan Kue dan Roti untuk Peningktan Kemampuan Kerja Siswa di SMK BPP Bawang. Bandung : LPPM Universitas Pendidikan Indonesia.

[11] Sugiyono. 2006. Metode Penelitian Kuantitatif, Kualitatif, dan R\&D. Bandung: alfabeta

[12] Sumartana. 2011. Pengaruh Pendekatan Product Based Training dan Pendekatan Competency Based Training pada Mata Pelajaran Praktik Pekerjaan Pemesinan Ditinjau dari Penguasaan dalam Menggunakan Alat Ukur. (Tesis). Universitas Negeri Semarang.

[13] Suryadi, Dedy dan Yusa, Ahmad Anwar. 2009. Model pembelajaran berbasis produksi dengan pendekatan asesmen portopolio pada perkuliahan praktik kerja bangunan. Jurnal penelitian. April 2009, Volume 9 No. 1.

[14] Widyabakti Sabatari dan Lilik Hariyanto. 2013. Upaya Pembelajaran Kewirausahaan di SMK Potret Komitmen Terhadap Standar Nasional Proses Pendidikan dan Pembelajaran. Jurnal Pendidikan dan Kejuruan, Mei 2013, Vol 21, Nomor 3 hal $285-293$

[15] Puyud, Deno dan Putra, Rusnardi. 2018. Meta Analisis Pengaruh Problem base Learning da Virtual laborotary terhadap Hasil Belajar Siswa. Invotek, Nomor 12018 , Volume 18.

\section{Biodata Penulis}

Irma Yulia Basri, merupakan dosen Jurusan Teknik Otomotif FT UNP, dengan latar Pendidikan S1 Pendidikan Teknik Elektronika FT UNP, S2 Teknik Elektro UGM. Saat ini mengajar pada mata kuliah Sensor dan Transduser, Listrik dan Elektronika dan autoCAD. 
Delsina Faiza, merupakan dosen Jurusan Teknik Elektronika FT UNP, dengan latar Pendidikan S1 Teknik Telekomunikasi STT Telkom, S2 Teknik Elektro ITB. . Saat ini mengajar pada mata kuliah Sistem Telekomunikasi, Matematika, Teknik Elektronika Lanjutan.

M. Nasir, Medan, Maret 1959, pendidikan S1 di Jurusn Teknik Otomotif FT UNP, S2 Teknologi Kurikulum Pasca Sarjana UNP merupakan dosen Jurusan Teknik Otomotif FT UNP mengajar di bidang
MMK, Listrik Elektronika Otomorif, dan Hidrolik Penumatik.

Nasrun, merupakan dosen Jurusan Teknik Otomotif FT UNP dengan latar belakang S1 Teknik Otomotif dan S3 Manajemen Pendidikan di IKIP Jakarta, dan saat ini mengampu mata kuliah Manjemen Industri dan Ekonomi Teknik. 
